\title{
CINEMA AS AN ELEMENT OF A STATE'S SOFT POWER SYSTEM
}

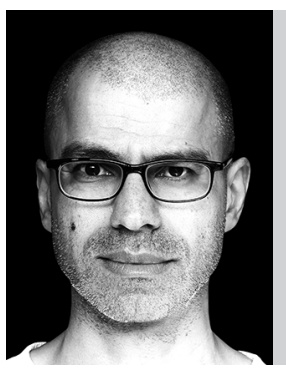

\section{Oliver Keune,}

Ural Federal University

named after the first President of Russia B.N.Yeltsin,

Associate professor,

PhD in philosophy,

Ekaterinburg, Russia,

E-mail: okeune@web.de

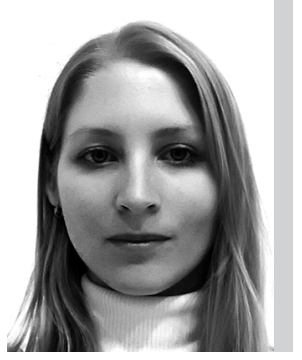

\section{Valeriya Frants,}

Ural Federal University

named after the first President of Russia B.N.Yeltsin,

Associate professor,

$\mathrm{PhD}$ in political science,

Ekaterinburg, Russia,

E-mail: val-franc@yandex.ru

\section{Annotation}

The article considers cinema as one of the most profitable cultural industries as well as a highly influential instrument of "soft power". the authors claim, however, that it's not enough to simply create a film in order to use it as a "soft power" tool. the article examines the ways of how a film can contribute to a positive image of the country, using the examples of the USA and China. It also takes a look at cinema within the system of a country's soft power instruments as well as in relation to the economy. Finally, the authors will analyze the situation and prospects of Russian cinema.

Key concepts:

cinema, soft power, creative industries, international image, political influence.

The strong potential of culture in general and cinema in particular as a tool of "soft power" was first seen by the creator of the concept of "soft power" - J. Nye. in his article "Soft power", published in 1990, the scientist calls sources of "soft power": 
"cultural and ideological attraction as well as rules and institutions of international regimes" [10]. Nye also emphasized the political importance of popular culture and stated that the positive effect of pop culture can make the process of carrying out policy more easy and effective. the scholar argued that "popular entertainment often contains subliminal images and messages about individualism, consumer choice, and other values that have important political effects" [11].

There are also a great number of other scholars considering cinema a powerful instrument of «soft power», foreign public opinion shaping, international political influence and so on. Thus, Street [15] discusses the complex connections between commercial culture and political power. the scientist invents the clever term 'packing of politics' to highlight that popular culture can be used as a powerful political tool due to its ability to articulate feelings that contribute to form the identity of individuals, including political thought and action. Wattenberg [17] is going even further claiming that "content is more powerful than politics or economics. It drives politics and economics". Zoysa and Newman [21] insist that through Hollywood, American cinema has become "part of the socialization process" for people around the world and "a prime mover in the globalization of consumerism and image making". Walt [16] notes: "America's leaders have sought to persuade as many countries as possible to embrace their particular vision of a liberal-capitalist world order. Hollywood is one of the cornerstones of this endeavor".

Not only scholars but also politicians appreciate the power of American popular culture. as an example we can name French politician Hubert Vedrine who states that Americans are so powerful because they can "inspire the dreams and desires of others, thanks to the mastery of global images through film and television and because, for these same reasons, large numbers of students from other countries come to the United States to finish their studies, quoted in [12].

Smith and Ricci emphasize that since the end of the First World War Europe recognized the need to counter Hollywood's domination of the movie marketplace for the balance of payments, protection of indigenous industries as well as preservation of national identity. Now we can say that this need is as real as it was a hundred years ago. to show the importance of the issue let's refer to the concepts of creative economy and creative industries, one of which is cinema.

According to UNCTAD, creative economy leverages creativity, technology, culture and innovation in fostering inclusive and sustained economic growth and development. Creative economy sectors include arts and craft, books, films, paintings, festivals, songs, designs, digital animation and video games. the creative economy is an important part of global trade. the global market for traded creative goods and services totaled $\$ 547$ billion in $2012^{1}$. Cross border trade of creative goods has shown sustained growth in the last decade. Growth rates stood at 8,6 percent annually from 2003 to 2012, showing the strength and resilience of the sector despite the economic deceleration of the world economy. Exports from developing countries, in particular Asia, are growing faster than in the developed world. the share of creative industries in the GDP of modern States is very high. So, according to Ernst \& Young, the total revenue of creative industries in the EU ( 28 countries) in 2012 has amounted

${ }^{1}$ Unfortunately, the latest statistics about the development of the global creative industries dates back to 2012 only. 
to $4,2 \%$ of the EU GDP. For comparison: the contribution of the real estate industry in the economy of the EU is $2,1 \%$, chemical industry (including the manufacture of plastic and rubber products) $-2,3 \%$, textile industry $-0,5 \%[5, \mathrm{p} .115]$. According to experts it will grow further.

As we can see, nowadays creative industries are strongly related to the economic prosperity of the countries that contributes to its international image. It also allows to influence other countries culturally. More people abroad admire the activities of some country's designers, architects, movies-makers, writers etc. more than they like that country in general. But where in the fields of literature, design, architecture etc. a lot of strong players from all over the world co-exist, in cinema there's undeniably just one worldwide leader: this is the USA, of course. in total, US films (including its domestic market) represent at least 70 percent of the global box office.

Currently, some countries have started to challenge Hollywood's worldwide domination. a bright example is China which actually pursues two goals: competing with Hollywood on one hand and using movies as part of its "soft power" strategy on the other hand. 2001 should be deemed a crucial date in Chinese history when the country joined the WTO (World Trade Organization). Even before, the importance of promoting China's culture and values had already been emphasized by government officials but only in 2001 the country was literally forced into inventing a strategy of becoming a global player also in cultural respect. It was President Hu Jintao who initiated a publicity wave in 2007, clearly pursuing the concept of "soft power". His successor, President Xi Jinping, already in 2007 used the 17th Central Committee of the Chinese Communist Party (CCP) to address the issue, "with the final communiqué declaring that it was a national goal to "build our country into a socialist cultural superpower" [14]. Xi later stated, that "We should increase China's soft power, give a good Chinese narrative, and better communicate China's messages to the world." a number of initiatives - "The Chinese dream", "The Asia-Pacific dream", "The Silk Road Economic Belt" and others - have been since brought into realization under his command [13].

As Dr. Weiying Peng [19, p. 43] states, the Beijing government, in several past years, has started to shift focus from investing in Confucius Institutes and ramping up Chinese media presence overseas by funding declining media like broadcast television and radio to produce pure propaganda programs toward more ostensibly pop areas, such as animation, commercial film, and online video gaming. in 2009, the State Council released its plan to adjust and reinvigorate the cultural industries and has formulated numerous sector-specific policies that target pop areas.

That is of interest, the reason to implement such a strategy was not only and not in the first place the competition with Hollywood, but the raise of so called "Korean Wave" that, in particular, made the influence of Korean culture and its cinema rather influential in the East Asia. Another country being traditionally considered by China as a more powerful cultural competitor is Japan. Cultural success of those two countries actually has one reason and route. in particular, as Keane [4, p. 93] says, Korea is successfully generating culture exports by "mixing traditional aesthetics with postmodern pop cultural sensibilities". According to McGray [9], while China is making a bet on its traditional culture, Japan markets its 'cool' contemporary pop 
and sub-culture in music, cuisine, anime, manga, video games and fashion through a public-private approach which encouraged and gave official blessing to the private sector to "sell the Japanese dream". As Aso [1] emphasized, "ironically, being cool, fun and hip have now become serious business for the Japanese state". Given that, Dr. Weiying Peng argues that the way to strengthen the influence of Chinese cinema overseas is to make it more universalistic and up to date. This way lies through the lowering the state regulation and growth of the coproduction's share in the total volume of China's cinema production. the scientist proves that by using examples and figures from China's recent past.

In 2012 the number of films produced in China reached 745, which is almost equal with India, and one of the highest totals in the world. in 2010, China's box office revenues skyrocketed, reaching RMB 10 billion, a 63,9 percent increase over the previous year. in 2012 Chinese domestic box office was RMB 17.073 billion, an annual growth rate of 30 percent. China surpassed Japan and became the second largest film market globally. These results were provided by implementation of some new regulations, especially "Interim Provisions on the Access of Operational Qualifications for Movie Production Distribution and Screening", "The Provisions on the Administration of Chinese-Foreign Cooperative Production of Films" and "Interim Provisions on Film Script Registration and Film Review". Such the policy opened access to active coproduction with such the countries as Hong Kong, Taiwan, USA, Australia etc. which allowed tapping into the internal market. However, overseas sales remained still insufficient.

The exception were such films like Crouching Tiger, Hidden Dragon (2000, directed by Li An/Ang Lee, \$USD 128 million box office), Hero (2002, directed by Zhang Yimou, \$USD 53,71 million box office) and Karate Kid earned RMB 2,4 billion outside China. At the same time films which were successful in China, did not perform well overseas. Lost in Thailand (2012) made 1200 million RMB. domestically in comparison to its overseas box office \$US 57000 and So Young (2013) made 700 million RMB compared to its overseas box office SUS 9990 (Li, H 2014: 119). to finalize it is suitable to quote Rosen's words that "Hollywood blockbuster films have in fact been far more effective in promoting China's public diplomacy initiatives than China's own films" [9].

Given the above described experience, the Chinese carried out an even more daring venture. It's about the specific type of co-production by which China targeted the American film market, trying to gain control (or at least some creative and financial leverage) over one of the most powerful tools to "shape" the image of an entire nation. Here the noticeable example is the activity of China's biggest e-commerce firm Alibaba. That company has put money in "Mission: Impossible Rogue Nation" (2015) [6]. the extremely successful "Furious 7" out of the "Fast and Furious" franchise was made with money from the China Film Group.LeTV, another large Chinese entertainment firm, started to establish offices in Los Angeles in 2015; Chinese film studio Huayi Bros. came to terms with American motion picture company STX entertainment to co-produce and co-distribute 12 to 15 films. and in January 2016, the Dalian Wanda Group bought the Los Angeles based studio Legendary Pictures - producer of such major hits like "Jurassic World", "Godzilla" and "Interstellar" - which made it the first Chinese film company that actually owns 
a Hollywood studio. the question as to whether all these attempts are or will be fruitful in the future is not yet decided. According to experts, China's success in campaigning its values is still modest. David Shambaugh, for example, states: "China's favorability ratings are mixed at best, and predominantly negative, and declining over time. They have dropped fully $20 \%$ from 2009 to 2015 " and Joseph S. Nye concedes: "China does better in Africa and Latin America than it does in its own neighborhood in Asia» [14]. However, in purely economic, that is: financial terms, China's strategy seems to be paying off.

As with Hollywood, the ironic situation is this: still being a contender one would expect fierce resistance from this market in order to protect itself. in fact, it's exactly the opposite. "Over the past decade, the number of tickets sold annually in the U.S. and Canada has sunk by 80 million" (Michael Lev-Ramm: Can China Save Hollywood? In: Fortune Entertainment, 2017). Confronted by a declining rate of movie-goers (also in Europe which used to be the most important market for Hollywood productions aside from their domestic audiences), and with profits shifting more to digital platforms as "Netflix" and other companies demonstrate, Hollywood producers already some time ago have begun to access the Chinese market with its 1.3 billion people. Nowadays, especially big-budgetproductions ( $\$ 150$ million and above) are more or less depending on financial success in Asia in order to retrieve their spending.

That's why in recent Hollywood productions a striking number of "casual" Chinese appearances was to be witnessed: in "Gravity", Chinese astronauts save American colleagues; in "The Martian" it's the China National Space Administration that decisively assists in bringing stranded astronaut Mark Watney (played by Matt Damon) back home. in the new Star Wars movie "Rogue One" Chinese film icons Donnie Yen and director/actor Wen Jiang had parts; "Independence Day: Resurgence" presents Americans and Chinese working together to save the world, featuring actress Angela Yeung Wing as an enticing fighter jet pilot; in "Mission Impossible 3" Tom Cruise races through the streets of Shanghai, and the "Transformers" fight in Hong Kong. Not to mention product placement: in "Independence Day: Resurgence" the characters use China's chat service QQ, or in "Captain America 3" Robert Downey Jr. uses a cell phone by Chinese company Vivo. None of these films obviously had financial support from China, and though not everyone was exactly thrilled with this kind of blunt advertising [18], it stands to reason that this agreement might easily be called a two-way-street, since it brought some (image) benefit to China and, in return, financial revenues to Hollywood movie producers.

However, this pattern does not always work as the example of "The Great Wall" shows: the film was the first serious experiment to combine creative and financial resources of the two film superpowers. Its story took place in China, featured Chinese mythology and topics, while its protagonist were white foreigners (which brought the film some criticism of "whitewashing") and it was filmed almost entirely in English. the director was Zhang Yimou (who could be regarded as one of the most influential film makers in China), the main actors were American film super heavyweights Matt Damon and Willem Dafoe.

From the American standpoint, the film indeed "worked", making in fact the biggest part of its earnings in China: $\$ 177$ millions against a total gross 
of \$331 million worldwide. (Admittedly, the film was still considered a financial failure due to its additional PR budget of reportedly above $\$ 80$ million). But the much bigger problem with the film was that it grossed only $\$ 45$ million in the US. and this is a problem for China, too, since "The Great Wall" was the very first collaboration of the two biggest movie industries in the world, trying to prove that with joined forces it is possible to produce a hit that will satisfy both audiences. the main producers were Universal Pictures and Wang Jianlin, the $2^{\text {nd }}$ richest man in China, founder of the Dalian Wanda Group which stands behind Legendary Entertainment (the other major producer of "The Great Wall"). Besides his investment in Hollywood, Wang Jianlin is also the owner of the upcoming Oriental Movie Metropolis studio, the biggest film studio in Asia. a man with great ambition, so to speak.

Like we said before, American audiences received the film quite cool. a reason might be that reviews by American critics and movie sites were not too favorable. as Rebecca Keegan writes, "Chinese moviegoers rely less on critic review aggregation sites like Rotten Tomatoes, and more on the audience scores posted on ticketing Web sites" (Rebecca Keegan: "Why Hollywood Needs Chinese Movie-goers More Than Ever This Summer». In: Vanity Fair, 2017). It is always hard to pinpoint why a movie did not turn out a success. But if it were like that that American and other non-Asian audiences just don't care too much about Chinese culture and imagery (or, even worse, are put off by the obvious "intent" behind China's "soft power" offensive), then China would really have a problem: spending billions of dollars in order to promote itself worldwide without actually augmenting its reputation. It will be interesting to see how this process develops in the future.

There are some reasons why China's example is of a great interest for Russia. First of all, as Russia recently, China pays a lot of attention to the development of comprehensive "soft power" strategy. Secondly, China is one of the biggest countries in the world with a growing demand. Thirdly, both countries have rather strong state regulations, including cinema development; both countries tend to make the traditional culture the basis of its "soft power". Finally, despite the fact that the popularity of Chinese cinema is still insufficient overseas, China managed to win the domestic market in a rather short time. Unfortunately, today's Russia can't boast of such a result.

With that in mind, let's consider the situation of the Russian movie industry. There are no accurate data of the number of films shot in Russia before 2005 . According to data provided by information agency "Inter Media" [2], it is known that in 200659 movies have been produced domestically, and in 2015, there it was already 138. This indicates a positive and stable development of the film industry. But amongst the 25 biggest releases on the Russian market for the period from 2002 to 2015, the number of domestic films was only 2. Russian domestic box office grosses are on average from 2 to 5 times less than revenues from Hollywood distributed films. Grosses from European releases are inferior in relation to both American and domestic movies. Hollywood blockbusters are the only category of films that consistently bring in good cash. Asian movies are the least popular.

It would be worthwhile to note that in 2015 for the first time the domestic box office top ten included no films produced in Russia. Also, every Russian film failed 
to reach the level of 1 billion RUB. For the last 14 years Russia has lost ground: no film produced in 2015 was in the top 25 of major films released since 2002. in 2015146 domestic and coproduced films were released. Only 17 of them were successful enough to exceed their production budget. This proves some stagnation: in 2010 only 11 films surpassed their budget but in 2011 and 2012 the quantity of successful films reached 20 . Thus, it can be said that film production still remains the weak side of the Russian film industry and most films don't pay off at the box office. This situation takes place while the government provides huge financial, institutional and legal support to the domestic film industry. in 2014 Russia spent 10798 million dollars to support culture industries, which is about 2 million more than China and 7,3 times more than the United States. the total box office, though, was 4 times less than in China and 8,6 times less than in USA. These figures show that even to win domestic audiences is still a challenge for Russia, not to mention the overseas one.

However, there are also some positive examples. Russian filmmakers succeed in the segment of computer 3D animation. Famous Russian animation Studio Wizart received large revenues from the film series "Snow Queen" in Russia and abroad. the franchise for these movies was sold to various countries around the world. Other examples are "Stalingrad" (\$USD 16,4 million box office), "Night Watch" (\$USD 17,7 million box office), "Siberian Barber" (\$USD 8,6 million box office). Here we see another tendency: that Russian history and flavor obviously generate public attention worldwide. At the same time, the box office of these films is at a minimum 3 times less than that of successful Chinese movies.

In this context it is ironic that Russia's current top director, Andrey Zvyagintsev, willingly or not willingly does exactly the opposite of what "soft power" officials in his country would expect: he even emphasizes the negatives in modern Russia, and he clearly draws a logical line between theses negatives and the government's actions [20]. That's why, in the case of "Leviathan" for example, Vladimir Medinski from Russia's Ministry of Culture, expressed such vital discontent with the film [8].

This all proves that Russia still can not find its way to lure worldwide audiences and therefore enhance its image through cinema "soft power". in our opinion it should tackle this challenge because of both economical and ideological reasons. Especially in light of powerful negative information campaigns by the US and Europe countries related to the Ukrainian crisis and the Syrian war conflict it could be a useful supplement to Russian information policy. But unfortunately in this field the perspectives are not very encouraging.

\section{References}

1. Aso, T. a New Look at Cultural Diplomacy: a Call to Japan's Cultural Practitioners. Retrieved August 8, 2017 from the sight of Ministry of Foreign Affairs of Japan: http://www.mofa.go.jp/announce/fm/aso/speech0604-2.html.

2. Film industry of Russian Federation in 2000-2015. Analytical Review. Retrieved August 8, 2017 from the sight of Information agency "Inter Media": http://www.intermedia.ru/uploads/Kinoind veb.pdf.

3. Is China's Soft Power Stragety Working? a talk with Joseph S. Nye Jr., 
Liz Economy and David Shambau. Retrieved August 8, 2017 from Centre for Strategic and International Studies: https://chinapower.csis.org/is-chinas-softpower-strategy-working/.

4. Keane, M. (2015). the Chinese Television Industry. London: Palgrave.

5. Kadachigov, R.V. (2015). Strategies for stimulating exports of creative industries in the European Union. Izvestia USUE, No. 6 (62). Pp. 114-125.

6. Kokas, A. Hollywood's obsession with China is just getting started. Retrieved February 13, 2017 from the International: http://www.businessinsider. de/hollywood-made-in-china-excerpt-2017-1? r=US\&IR=T.

7. Lev-Ramm, M. Can China Save Hollywood? Retrieved May 22, 2017 from Fortune Entertainment: file://Users/ok/Desktop/Websites\%20China\%20 Soft $\% 20$ Power/Can $\% 20$ China $\% 20$ Save $\% 20$ Hollywood $\% 3 F \% 20 \mid \% 20$ Fortune. com.html.

8. MacFarqhar, N. Russian Movie 'Leviathan' Gets Applause in Hollywood but Scorn at Home. Retrieved January 27, 2015 from the New York Times: https:// www.nytimes.com/2015/01/28/world/europe/leviathan-arussian-movie-getsapplause-in-hollywood-but-scorn-at-home.html.

9. McGray, D. (2002). Japan's gross national cool. Foreign Policy, No. 130 (May/June). Pp. 44-54.

10. Nye, J. (1990). Soft Power. Foreign Policy, No. 80 (Twentieth Anniversary). P.168.

11. Nye, J.S. Soft power and higher education. Retrieved July 12, 2015 from the Future of Higher Education, EDUCAUSE.: http://www.educause.edu/ Resources/SoftPowerandHigherEducation/.

12. Nye, J.S. (2002). the Paradox of American Power: Why the world is only superpower can it go it alone. NY: Oxford University Press.

13. Rosen, S. (2011). the Use of Film for Public Diplomacy: Why Hollywood Makes a Stronger Case for China. Retrieved Janurary 15, 2015, from USC Annenberg: http://uscpublicdiplomacy.org/pdin_monitor_article/the use_of film for_public_diplomacy_why_hollywood_makes_a_stronger_case_fo.

14. Shambaugh, D. (2015). China's $\overline{\text { Soft }}$ Power $\overline{\text { Push. Retrieved }}$ July/August 2015 from Foreign Affairs: https://www.foreignaffairs.com/articles/ china/2015-06-16/china-s-soft-power-push.

15. Street, J. (1997). Politics and Popular Culture. Oxford: Blackwell. Norton.

16. Walt, S.M. (2006). Taming American Power. New York, NY: WW

17. Wattenberg, B.J. (1991). the first universal nation: leading indicators and ideas about the surge of America in the 1990s. New York: Free Press.

18. Wei Xi. Chinese audiences unhappy with clumsy product placement. Retrieved June 29, 2016 from Global Times.

19. Weiying Peng (2015). China, Film Coproduction and Soft Power Competition (PhD dissertation). Queensland University of Technology.

20. Zeitchik, S. Cannes 2017: a new film slyly critiques Russia (just don't tell the director). Retrieved May 20, 2017 from Los Angeles Times.

21. Zoysa, R.D., \& Newman, O. (2002). Globalization, soft power and the challenge of Hollywood. Contemporary Politics, 8 (3). Pp. 185-202. 


\section{КИНЕМАТОГРАФ КАК ЭЛЕМЕНТ СИСТЕМЫ «МЯГКОЙ СИЛЫ» ГОСУДАРСТВА}

\section{Оливер Койне,}

Уральский федеральный университет

им. первого Президента России Б.Н. Ельцина, доцент кафедры ИМК и брендинга,

кандидат философских наук,

Екатеринбург, Россия,

E-mail: okeune@web.de

\section{Валерия Франц,}

Уральский федеральный университет

им. первого Президента России Б.Н. Ельцина, доцент кафедры ИМК и брендинга, кандидат политических наук, Екатеринбург, Россия,

E-mail: val-franc@yandex.ru

\section{Аннотация}

В рамках статьи кинематограф рассматривается как наиболее прибыльная культурная индустрия, а также как мощный инструмент «softpower». Однако авторы утверждают, что недостаточно просто создать фильм, который автоматически станет проводником «мягкой силы». В статье на примерах американского и китайского кинематографа рассматриваются пути и методы создания фильмов, способных внести вклад в формирование положительного образа государства. Статья также проливает свет на место кинематографа среди других инструментов «softpower» государства и его взаимосвязь со сферой экономики. Полученные результаты позволяют авторам проанализировать актуальное состояние и перспективы российского кинематографа.

Ключевые понятия:

кинематограф, soft power, творческие индустрии, международный имидж, политическое влияние. 